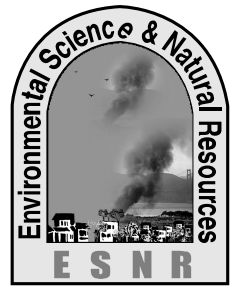

\title{
In Vitro Regeneration of High Yielding Indica Rice (Oryza sativa L.) Varieties
}

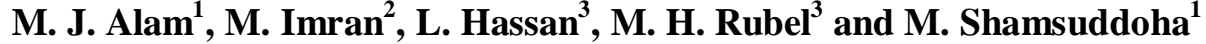 \\ ${ }^{1}$ Supreme Seed Company Limited \\ ${ }^{2}$ Dept. of Environmental Science, Bangladesh Agricultural University, Mymensingh. \\ ${ }^{3}$ Dept. of Genetics and Plant Breeding, Bangladesh Agricultural University, Mymensingh
}

\begin{abstract}
The experiment was conducted to observe the regeneration potential and also to establish a suitable in vitro plantlet regeneration protocol from mature seed derived embryogenic calli of four indica rice varieties viz BRRI dhan28, BRRI dhan29, BRRI dhan47 and Binadhan-7 after partial desiccation treatment. Different concentrations and combinations of growth regulators were used in MS medium to observe the callus induction ability using mature embryo as explants. The percentage of callus induction frequency was highest (86.00) in BRRI dhan47 and the lowest (56.50) in Binadhan-7 Among the culture media the performance of MS +500 $\mathrm{mgl}^{-1} \mathrm{~L}$ - Proline $+2.0 \mathrm{mgl}^{-1} 2,4-\mathrm{D}+0.8 \mathrm{mgl}^{-1} \mathrm{BAP}$ was better than any other media for callus induction frequency $(\%)$, rapid callusing, size of the callus (mm), texture of callus and color of callus. Among the four varieties, shoot regeneration was highest in BRRI dhan29 (84.33\%) which required minimum (14.80) days to and the lowest was in Binadhan-7 (39.67\%) which required maximum (15.47) days. Among the treatments, the highest $(65.75 \%)$ shoot regeneration was observed with $\mathrm{MS}+6.0 \mathrm{mgl}{ }^{-1} \mathrm{Kn}+$ $0.5 \mathrm{mgl}^{-1}$ NAA which required minimum days (13.75) to develop green bud formation and the lowest shoot regeneration (56.50) was observed with MS $+2.0 \mathrm{mgl}^{-1} \mathrm{Kn}+.05 \mathrm{mgl}^{-1} \mathrm{NAA}$. BRRI dhan29 produced more number of shoots (4.67) per callus while Binadhan-7 showed minimum number of shoots (2.87) per callus. The highest number of shoot producing roots (3.66) was observed in BRRI dhan29 which showed maximum number of root per plant and the lowest (3.11) in Binadhan-7. Among the three treatments $\mathrm{MS}+0.6 \mathrm{mgl}^{-1} \mathrm{IBA}$ showed highest percentage 86.67 of root followed by $\mathrm{MS}+0.6 \mathrm{mgl}^{-1} \mathrm{IBA} 70 \%$ and the lowest $(66.7 \%)$ was in MS+ $0.4 \mathrm{mgl}^{-1} \mathrm{IBA}$. The establishment rate of the plantlet in the pot was the highest (67.67\%) in BRRI dhan29 and Binadhan-7 showed lowest establishment rate $(51.22 \%)$ in pot.
\end{abstract}

Key words: Desiccation, Explant, IBA, Plantlet, Regeneration

\section{Introduction}

Rice, Oryza sativa $(2 \mathrm{n}=2 \mathrm{x}=24)$, an annual grass, belongs to the family Graminae, is the staple food for the people of Bangladesh. Rice provides as much as $80 \%$ of the required calories for people in Bangladesh. At present genus, Oryza consists of two cultivated species and twenty one wild species. Oryza sativa is an Asian cultivated rice, grown worldwide, while Oryza glaberrima is grown only in limited areas of West Africa. There are three sub species on the basis of ecogeographical races. Oryza sativa is recognized into three sub species namely indica, japonica and javanica. Among these indica is most widely cultivated in the humid regions of Asian tropics and subtropics. But japonica is limited to temperate regions and javanica is mainly grown in some parts of Indonesia (Chang et al., 2003). Indica type rice varieties are consumed by more than two billion people and accounts for $80 \%$ of cultivated rice of the world (Dutta et al., 1999). It provides $27 \%$ of dietary energy supply in the developing world. In much of Asia, rice is so central to the culture that the word is almost synonymous with food.

Efficient plant regeneration in in vitro is essential for the successful utilization of biotechnology in rice crop improvement. Rice production showed record increases during the last three decades of the $20^{\text {th }}$ century, beginning with the pre-green revolution. In many Asian countries, rice yield levels are doubled or tripled from the pre-green revolution with an average of 1.9 tons per hectare (FAO, 2004). Average per capita food availability was $18 \%$ higher in 2000 than in 1966 (Khush, 2004). In Asia, it is projected that demand for rice will increase by $70 \%$ over the next 30 years, driven primarily by population growth, excluding China, is expected to increase by $51 \%$ (Hossain, 1997). To keep pace with projected demand, rice production growth must be sustained at $3 \%$ per year.

At present, International Rice Research Institute (IRRI) is employing tissues culture technique to develop rice varieties (Bajaj, 1996). Various tissue culture techniques are being applied for varietal development of cereal crops including rice in different countries (Dorosieve, 1996). Among these techniques, anther culture, protoplast fusion, leaf culture, root culture and dehusked seed culture are important in rice tissue culture to exploit somaclonal variation for creation of novel rice varieties.Therefore, the experiment was undertaken considering the following objectives: i) to find out the potentiality of high yielding indica rice (sativa L.) varieties for callus induction and plant regeneration from their mature dehusked seeds, ii)to find out the suitable concentration of BAP for callus induction 
and iii) to study the single and combined effects of different cytokinine and auxin on plantlet regeneration.

\section{Materials and Methods}

Four indica rice Bangladeshi varieties viz BRRI dhan28, BRRI dhan29, BRRI dhan47 and Binadhan-7 were used in this experiment. Mature embryo was the main source of explant.

The following growth regulators and phytohormone supplements were used in the present study:

Auxins 2, 4- dichlorophenoxy acetic acid (2, 4-D); $\alpha$ - naphthalene acetic avid (NAA); Indole butyric acid (IBA)

Cytokinins 6-furfuryl amino purine (Kinetin); 6benzyl amino purine (BAP)

\section{Amino acid L- Proline}

The different media combination for callus induction were MS + $500 \mathrm{mg} / \mathrm{l} \mathrm{L}$ - Proline + $2.0 \mathrm{mg} / 1$ 2, 4-D + 0.2/ 0.4/0.6/0.8 mg/l- 1 BAP (T1-4), for shoot induction $\mathrm{MS}+0.5 \mathrm{mg} / \mathrm{l} \mathrm{NAA}+2.0 / 4.0 / 6.0 \mathrm{mg} / \mathrm{l}$ Kinetin (T1-3) and root induction MS + 0.2/0.4/0.6 $\mathrm{mg} / \mathrm{l}$ IBA (T1-3)

\section{Results and Discussion}

In vitro plant regeneration via calli offer an unique facility of reproducible protocol as well as create somaclonal variations for further crop improvement. Investigation of in vitro regeneration of these varieties was accomplished with callus induction, callus characters, organogenesis, plantlet regeneration and subsequently their establishment in the field. The first step of this experiment was callus induction followed by plantlet regeneration. 50 explants were distributed in five replicates. The combine effects of varieties and treatments on different characters of calli were presented in the Table 1.

The percentage of callus induction frequency was the highest (86.00) in BRRI dhan 47 which required 14.90 days \& the lowest (56.50) in BINA dhan7 which required minimum days (14.65). Among the culture media the performance of MS+2,4-D+LProline+BAP (mgl) was better than any other media for callus induction, rapid callusing, size of the callus $(\mathrm{mm})$, texture of callus and color of callus . MS+2,4D+L-Proline+BAP (mgl) was showed the lowest percentage callus induction, maximum days required for callusing, size of the callus, texture of callus \& color of callus. The biggest size of callus $2.41 \mathrm{~mm}$ was identified from BRRI dhan 29 and most compact $2.48 \mathrm{~mm}$ calli was also produced by BRRI dhan 29 .

Table 1. Effects of varieties in combination with treatments on different characters of calli induced in vitro from mature embryos of four indica rice (sativa L.) genotypes at two to three weeks of explanation (50 explant were incubated for each treatment)

\begin{tabular}{|c|c|c|c|c|c|c|}
\hline Variety & $\begin{array}{l}\text { MS+2,4-D+L- } \\
\text { Proline+BAP } \\
(\mathrm{mg} / \mathrm{l})\end{array}$ & $\begin{array}{l}\text { Days to } \\
\text { callusing }\end{array}$ & $\begin{array}{c}\text { Callus } \\
\text { induction } \\
\text { Frequency } \\
(\%)\end{array}$ & $\begin{array}{l}\text { Size of } \\
\text { callus } \\
(\mathrm{mm})\end{array}$ & $\begin{array}{l}\text { Texture of } \\
\text { callus }\end{array}$ & $\begin{array}{c}\text { Colour of } \\
\text { callus }\end{array}$ \\
\hline \multirow[t]{4}{*}{ BRRI dhan28 } & $2.0+500+0.2$ & $16.00 \mathrm{a}$ & $70.00 \mathrm{hi}$ & $2.16 \mathrm{ef}$ & $2.41 \mathrm{a}-\mathrm{e}$ & $2.93 \mathrm{a}$ \\
\hline & $2.0+500+0.4$ & $15.80 \mathrm{ab}$ & $76.00 \mathrm{fg}$ & $2.24 \mathrm{~d}-\mathrm{f}$ & $2.52 \mathrm{ab}$ & $2.05 \mathrm{f}$ \\
\hline & $2.0+500+0.6$ & $15.60 \mathrm{ab}$ & $64.00 \mathrm{j}$ & $2.28 \mathrm{~d}-\mathrm{f}$ & $2.35 \mathrm{c}-\mathrm{e}$ & $2.85 \mathrm{ab}$ \\
\hline & $2.0+500+0.8$ & $15.40 \mathrm{a}-\mathrm{c}$ & $82.00 \mathrm{c}-\mathrm{e}$ & $2.34 \mathrm{c}-\mathrm{e}$ & $2.48 \mathrm{a}-\mathrm{d}$ & $2.68 \mathrm{~b}$ \\
\hline \multirow[t]{4}{*}{ BRRI dhan29 } & $2.0+500+0.2$ & $16.00 \mathrm{a}$ & $80.00 \mathrm{~d}-\mathrm{f}$ & $2.38 \mathrm{~b}-\mathrm{d}$ & $2.46 \mathrm{a}-\mathrm{d}$ & $2.39 \mathrm{c}$ \\
\hline & $2.0+500+0.4$ & $16.20 \mathrm{a}$ & $74.00 \mathrm{gh}$ & $2.44 \mathrm{~b}-\mathrm{d}$ & $2.38 \mathrm{~b}-\mathrm{e}$ & $1.85 \mathrm{~g}$ \\
\hline & $2.0+500+0.6$ & $14.60 \mathrm{~b}-\mathrm{d}$ & $90.00 \mathrm{ab}$ & $2.56 a b$ & $2.52 \mathrm{ab}$ & $1.71 \mathrm{gh}$ \\
\hline & $2.0+500+0.8$ & $15.40 \mathrm{a}-\mathrm{c}$ & $86.00 \mathrm{bc}$ & $2.26 \mathrm{~d}-\mathrm{f}$ & $2.56 \mathrm{a}$ & $2.94 \mathrm{a}$ \\
\hline \multirow[t]{4}{*}{ BRRI dhan47 } & $2.0+500+0.2$ & $15.40 \mathrm{a}-\mathrm{c}$ & $92.00 \mathrm{a}$ & $2.10 \mathrm{f}$ & $2.33 \mathrm{de}$ & $2.3 \mathrm{c}-\mathrm{e}$ \\
\hline & $2.0+500+0.4$ & $15.00 \mathrm{a}-\mathrm{c}$ & $78.00 \mathrm{e}-\mathrm{g}$ & $2.66 \mathrm{a}$ & $2.41 \mathrm{~b}-\mathrm{e}$ & $1.59 \mathrm{~h}$ \\
\hline & $2.0+500+0.6$ & $13.40 \mathrm{de}$ & $84.00 \mathrm{~cd}$ & $2.30 \mathrm{~d}-\mathrm{f}$ & $2.45 \mathrm{a}-\mathrm{d}$ & $2.33 \mathrm{~cd}$ \\
\hline & $2.0+500+0.8$ & $15.80 \mathrm{ab}$ & $90.00 \mathrm{ab}$ & $2.52 \mathrm{a}-\mathrm{c}$ & $2.49 \mathrm{a}-\mathrm{c}$ & $2.41 \mathrm{c}$ \\
\hline \multirow[t]{4}{*}{ Binadhan-7 } & $2.0+500+0.2$ & $15.40 \mathrm{a}-\mathrm{c}$ & 52.001 & 2.14 ef & $2.29 \mathrm{e}$ & $2.11 \mathrm{ef}$ \\
\hline & $2.0+500+0.4$ & $14.20 \mathrm{~cd}$ & 48.001 & $2.32 \mathrm{de}$ & $2.38 \mathrm{~b}-\mathrm{e}$ & $2.40 \mathrm{c}$ \\
\hline & $2.0+500+0.6$ & $16.20 \mathrm{a}$ & $58.00 \mathrm{k}$ & $2.26 \mathrm{~d}-\mathrm{f}$ & 2.41 a-e & $1.83 \mathrm{~g}$ \\
\hline & $2.0+500+0.8$ & $12.80 \mathrm{e}$ & $68.00 \mathrm{ij}$ & $2.660 \mathrm{a}$ & $2.35 \mathrm{c}-\mathrm{e}$ & $2.15 \mathrm{~d}-\mathrm{f}$ \\
\hline $\mathbf{L S D}_{(0.05)}$ & & 1.162 & 4.619 & 0.174 & 0.128 & 0.196 \\
\hline
\end{tabular}


The interaction between genotypes and different growth hormone combinations was highly significant for those callusing parameter. The results of the analysis of variance (mean squares) on parameters for different varieties and media combinations of phytohormone were presented in Table 2.

Table 2. Analysis of variances of mean square values for callusing parameters of four indica rice varieties

\begin{tabular}{|c|c|c|c|c|c|c|}
\hline \multirow{2}{*}{$\begin{array}{c}\text { Sources of } \\
\text { variation }\end{array}$} & \multirow[t]{2}{*}{ df } & \multicolumn{5}{|c|}{ Mean of square } \\
\hline & & $\begin{array}{l}\text { Days to } \\
\text { callusing }\end{array}$ & $\begin{array}{c}\text { Callus } \\
\text { induction } \\
\text { frequency }(\%)\end{array}$ & $\begin{array}{l}\text { Size of callus } \\
\quad(\mathbf{m m})\end{array}$ & $\begin{array}{c}\text { Texture of } \\
\text { callus }\end{array}$ & $\begin{array}{c}\text { Colour of } \\
\text { callus }\end{array}$ \\
\hline Variety & 3 & $3.060 * *$ & $2090.00^{* *}$ & $0.059^{* *}$ & $0.031 * *$ & $0.653 * *$ \\
\hline Treatment & 3 & $1.780 * *$ & $322.00 * *$ & $0.149^{* *}$ & $0.019 * *$ & $0.796 * *$ \\
\hline $\begin{array}{l}\text { Variety } x \text { Treatme } \\
\text { (Interaction) }\end{array}$ & 9 & $3.293 * *$ & $117.33 * *$ & $0.082 * *$ & $0.013^{*}$ & $0.409 * *$ \\
\hline Error & 32 & 0.488 & 7.713 & 0.011 & 0.006 & 0.014 \\
\hline
\end{tabular}

$*$ = Significant at $5 \%$ level of probability

$* *=$ Significant at $1 \%$ level of probability

$\mathrm{df}=$ Degree of freedom

Among the four varieties shoot regeneration was the highest in BRRI dhan29 (84.33\%) which required only 14.80 days for green bud formation and the lowest in Binadhan-7 (39.67\%) which required maximum 15.47 days for green bud formation (Table 3.). Among the treatments, the highest $(65.75 \%)$ shoot regeneration was observed with $\mathrm{MS}+\mathrm{NAA}+\mathrm{Kn}$ $\left(\mathrm{mgl}^{-1}\right)$ which required minimum days (13.75) to green bud formation and the lowest shoot regeneration $(56.50 \%)$ was observed with MS + $\mathrm{NAA}+\mathrm{Kn}\left(\mathrm{mgl}^{-1}\right)$. BRRI dhan29 produced more number of shoots (4.67) per callus while Binadhan-7 showed minimum number of shoots (2.87) per callus.

Table 3. Effects of varieties in combination with treatments on different shooting parameters of callus induced in vitro from mature embryos of four indica rice (Oryza sativa L.) genotypes

\begin{tabular}{|c|c|c|c|c|}
\hline Varieties & $\mathrm{MS}+\mathrm{NAA}+\mathrm{Kn}\left(\mathrm{mgl}^{-1}\right)$ & $\begin{array}{l}\text { Days to green bud } \\
\text { formation }\end{array}$ & $\begin{array}{l}\text { Percent callus } \\
\text { regeneration }\end{array}$ & $\begin{array}{l}\text { Average no of shoot per } \\
\text { callus }\end{array}$ \\
\hline \multirow[t]{3}{*}{ BRRI dhan28 } & $0.5+2.0$ & $15.80 \mathrm{~b}-\mathrm{e}$ & $67.67 \mathrm{c}$ & $2.60 \mathrm{~h}$ \\
\hline & $0.5+4.0$ & $16.80 \mathrm{ab}$ & $63.00 \mathrm{~d}$ & $2.80 \mathrm{gh}$ \\
\hline & $0.5+6.0$ & $13.60 \mathrm{f}$ & $67.00 \mathrm{c}$ & 3.20 ef \\
\hline \multirow[t]{3}{*}{ BRRI dhan29 } & $0.5+2.0$ & $16.20 \mathrm{~b}-\mathrm{d}$ & $78.00 \mathrm{~b}$ & $4.60 \mathrm{bc}$ \\
\hline & $0.5+4.0$ & $17.40 \mathrm{a}$ & $81.00 \mathrm{~b}$ & $5.60 \mathrm{a}$ \\
\hline & $0.5+6.0$ & $10.80 \mathrm{~g}$ & $94.00 \mathrm{a}$ & $3.80 \mathrm{~d}$ \\
\hline \multirow[t]{3}{*}{ BRRI dhan47 } & $0.5+2.0$ & $16.40 \mathrm{bc}$ & $56.00 \mathrm{e}$ & $2.60 \mathrm{~h}$ \\
\hline & $0.5+4.0$ & $13.60 \mathrm{f}$ & $41.00 \mathrm{f}$ & $3.00 \mathrm{fg}$ \\
\hline & $0.5+6.0$ & $14.80 \mathrm{e}$ & $58.00 \mathrm{e}$ & $3.40 \mathrm{e}$ \\
\hline \multirow[t]{3}{*}{ Binadhan-7 } & $0.5+2.0$ & $15.40 \mathrm{c}-\mathrm{e}$ & $34.00 \mathrm{~g}$ & $4.40 \mathrm{c}$ \\
\hline & $0.5+4.0$ & $15.20 \mathrm{de}$ & $41.00 \mathrm{f}$ & $4.80 \mathrm{~b}$ \\
\hline & $0.5+6.0$ & $15.80 \mathrm{~b}-\mathrm{e}$ & $44.00 \mathrm{f}$ & $4.60 \mathrm{bc}$ \\
\hline $\operatorname{LSD}_{(0.05)}$ & & 0.924 & 3.972 & 0.266 \\
\hline
\end{tabular}

The interaction between genotypes and different growth hormone combinations was highly significant for those shooting parameter. These values (mean squares) were presented in Table 4. 
Table 4. Analysis of variance of mean square values for shooting parameters of four indica rice varieties

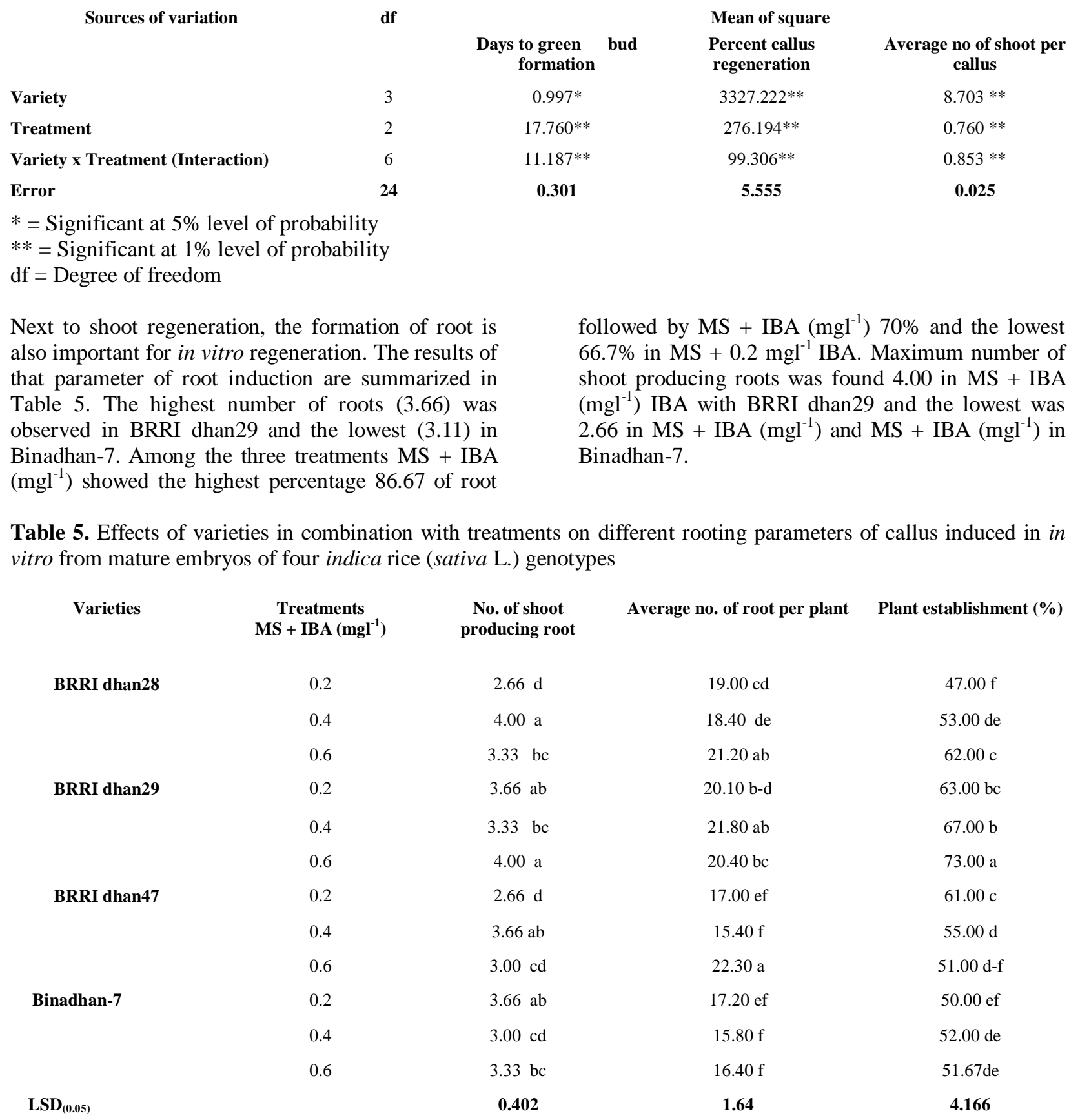

The result of the analysis of variance (mean squares) values for rooting parameters were presented in Table 6. 
Table 6. Analysis of variance of mean square values for rooting parameters of four indica rice varieties

\begin{tabular}{|c|c|c|c|c|}
\hline \multirow[t]{2}{*}{ Sources of variation } & \multirow[t]{2}{*}{ df } & \multicolumn{3}{|c|}{ Mean of square } \\
\hline & & $\begin{array}{c}\text { No. of shoot } \\
\text { producing root }\end{array}$ & $\begin{array}{c}\text { Average no. of root per } \\
\text { plant }\end{array}$ & Plant establishment (\%) \\
\hline Variety & 3 & $0.474 * *$ & $30.483 * *$ & $473.583 * *$ \\
\hline Treatment & 2 & $0.371 * *$ & $16.477 * *$ & $53.444 * *$ \\
\hline Variety $\times$ Treatment (Interaction) & 6 & $0.805^{* *}$ & $11.041^{* *}$ & $91.000 * *$ \\
\hline Error & 24 & 0.057 & 0.941 & 6.112 \\
\hline
\end{tabular}

From this experiment, it could be concluded that the best performer BRRI dhan 47 induced best calli with media combination of MS supplemented with $2 \mathrm{mgl}^{-1}$ 2,4-D + $0.8 \mathrm{mgl}^{-1} \mathrm{BAP}+500 \mathrm{mgl}^{-1} \mathrm{~L}$ - Proline. BRRI dhan29 in MS supplemented with $6.0 \mathrm{mgl}^{-1} \mathrm{Kn}+0.5$ $\mathrm{mgl}^{-1}$ NAA performed well in case of regeneration. BRRI dhan29 showed the best performance in producing maximum roots per shoot as well as percent plant establishment in combination with MS supplemented with $0.5 \mathrm{mgl}^{-1}$ IBA.

\section{References}

Aditya, T.L., Hoque, M. E and Khalequzzaman, M. 2004. Response to high frequency callus induction ability from root regions of germinated embryo in indica rice. Pak. J. Biol. Sci., 7(5): 861-864.

Bajaj, S. and Rajam, M.V. 1996. Efficient plant regeneration from long term callus cultures of rice by spermidine. Plant Cell Rep., 14: 717-720.

Chang, M., Hu, T., Layton, J.I., Liu, C.N. and Fry, J.E. 2003. Desiccation of plant tissues post Agrobacterium infection enhances T- DNA delivery and increases stable transformation efficiency in wheat. In Vitro Cell Dev. Biol. Plant., 39: 595-604.

Deepti, S., Shankhdhar, S.C. and Pant, R.C. 2001. Genotypic variation of callus induction and plant regeneration in rice (Oryza sativa L.). Indian $J$. Plant Physiol., 6(3): 261-264.

Dutta, K., Velazhahan, R., Baisakh, N., Oliva, N. and Datta, S.K. 1999. Over expression of the cloned rice thaumatin-like protein (PR-5) gene in transgenic rice plants enhanced environmental friendly resistance to Rhizoctonia solani causing sheath disease. Theor. Appl. Genet. 98: 11381145 .

Food and Agriculture Organization (FAO). 2004. Rice is Life. Italy: FAO, http://www.fao.org/newsroom/en/focus/2004368 87/index.html.

Hossain, M. 1997. Rice supply and demand in Asia: a socioeconomic and biophysical analysis. In: Applications of systems approaches at the farm and regional level. Dordrecht: Kluwer Aca. Pub. 124-129pp.

Khush, G. 2004. Harnessing science and technology for sustainable rice based production system. Presented at the FAO rice conference, Rome, Italy. 12-13pp. 